University of Nebraska - Lincoln

DigitalCommons@University of Nebraska - Lincoln

Agronomy \& Horticulture -- Faculty Publications

Agronomy and Horticulture Department

2009

\title{
Farmers and nature conservation: What is known about attitudes, context factors and actions affecting conservation?
}

\author{
Johan Ahnström \\ Swedish University of Agricultural Sciences, johan.ahnstrom@ekol.slu.se \\ Jenny Höckert \\ Swedish University of Agricultural Sciences \\ Hanna L. Bergea \\ Swedish University of Agricultural Sciences \\ Charles Francis \\ University of Nebraska-Lincoln, cfrancis2@unl.edu \\ Peter Skelton \\ New Mexico State University
}

See next page for additional authors

Follow this and additional works at: https://digitalcommons.unl.edu/agronomyfacpub

Part of the Plant Sciences Commons

\begin{abstract}
Ahnström, Johan; Höckert, Jenny; Bergea, Hanna L.; Francis, Charles; Skelton, Peter; and Hallgren, Lars, "Farmers and nature conservation: What is known about attitudes, context factors and actions affecting conservation?" (2009). Agronomy \& Horticulture -- Faculty Publications. 361.

https://digitalcommons.unl.edu/agronomyfacpub/361
\end{abstract}

This Article is brought to you for free and open access by the Agronomy and Horticulture Department at DigitalCommons@University of Nebraska - Lincoln. It has been accepted for inclusion in Agronomy \& Horticulture -Faculty Publications by an authorized administrator of DigitalCommons@University of Nebraska - Lincoln. 


\section{Authors}

Johan Ahnström, Jenny Höckert, Hanna L. Bergea, Charles Francis, Peter Skelton, and Lars Hallgren 


\title{
Farmers and nature conservation: What is known about attitudes, context factors and actions affecting conservation?
}

\author{
Johan Ahnström ${ }^{1, *}$, Jenny Höckert ${ }^{2}$, Hanna L. Bergeå ${ }^{2}$, Charles A. Francis ${ }^{3,} \dagger$, Peter Skelton ${ }^{4}$ \\ and Lars Hallgren ${ }^{2}$ \\ ${ }^{1}$ Department of Ecology, Swedish University of Agricultural Sciences, Box 7023, S75007, Uppsala, Sweden. \\ ${ }^{2}$ Department of Urban and Rural Development, Swedish University of Agricultural Sciences, Box 7012, SE75007, \\ Uppsala, Sweden. \\ ${ }^{3}$ University of Nebraska, 102B KCR, Lincoln, NE 68583-0915, USA. \\ ${ }^{4}$ New Mexico State University, Las Cruces, NM 87701, USA. \\ *Corresponding author: johan.ahnstrom@ekol.slu.se
}

\begin{abstract}
Farmers' attitudes towards viability of specific conservation practices or actions strongly impact their decisions on adoption and change. This review of 'attitude' information reveals a wide range of perceptions about what conservation means and what the impacts of adoption will mean in economic and environmental terms. Farmers operate in a tight financial situation, and in parts of the world they are highly dependent on government subsidies, and cannot afford to risk losing that support. Use of conservation practices is most effective when these are understood in the context of the individual farm, and decisions are rooted in land and resource stewardship and long-term concerns about health of the farm and the soil. The attitudes of farmers entering agri-environmental schemes decide the quality of the result. A model is developed to show how attitudes of the farmer, the farming context and agri-environmental schemes interact and thus influence how the farming community affects nature and biodiversity. As new agri-environmental schemes are planned, agricultural development specialists need to recognize the complexity of farmer attitudes, the importance of location and individual farmer circumstances, and the multiple factors that influence decisions. We provide these insights and the model to conservation biologists conducting research in farming areas, decision makers who develop future agri-environmental schemes, educators training tomorrow's extension officers and nature conservationists, and researchers dealing with nature conservation issues through a combination of scientific disciplines.
\end{abstract}

Key words: attitude, biodiversity, stewardship, agri-environmental scheme

\section{Introduction}

Agricultural production methods have to be sustainable in economic, ecological, and social terms, in order to provide food for the growing global population. However, agricultural intensification and specialization have resulted in declining biodiversity and other environmental problems in agro-ecosystems ${ }^{1-3}$. Society has created nature conservation and environmental programs to counter these negative

$\dagger$ Present address: Norwegian University Life Sciences, PO 5003, NO-1432, Norway. trends, e.g. agri-environmental schemes within the European Union (EU); these programs compensate farmers for the production of common goods and services but also for adopting environmentally friendly production strategies. Environmental programs in farmland are by necessity mediated through farmers, whose decisions on land management are affected by the programs and schemes but also other factors ranging from municipality regulations to general norms in the society. It is often uncertain how farmers will react to specific incentive strategies, but the choice is dependent in large parts on the farmers' attitudes and norms.

Siebert et al. ${ }^{4}$ describe the integration of agriculture and biodiversity conservation as becoming a truism in the EU. 
Unfortunately, the evaluations of the different schemes are few, and most existing evaluations are neither published in peer-reviewed journals nor analyzed with proper statistics $^{5-7}$. Further, the evaluations are hard to perform because schemes often have multiple goals ranging from purely ecological objectives to public enjoyment ${ }^{8}$. A major problem in the design of schemes and the supporting research is that farmers' perceptions and knowledge of nature often are neglected. According to a search in ISI Web of Knowledge using the key words nature conservation and attitudes, only $4 \%$ of the papers dealing with nature conservation issues also mentioned farmers' attitudes.

Knop et al. ${ }^{7}$ conclude that to create efficient agrienvironmental schemes it is necessary to build in possibilities for regional and local adaptations of the prescribed management. Bengtsson et al. $^{9}$ argue that large-scale schemes such as those imposed by the EU need to be more farm and landscape specific. Farming, nature conservation and biodiversity are not static and will change, and thus advice and schemes have to be adaptable to new circumstances. When working on a socio-economic unit such as a farm, which is embedded within a larger landscape and economic/social environment, agri-environmental schemes should consider a number of ecological scales and include different disciplines, such as natural and social sciences and economics ${ }^{10}$. Biodiversity is positively associated with high landscape heterogeneity ${ }^{11,12}$. Firbank $^{12}$ argues that more heterogeneity in the landscape would be one result of less rigid schemes with more reliance on the farmer to operate in a sound way. However, some organisms often depend on landscape factors or parameters not included in the scheme ${ }^{13}$.

Development of schemes has increasingly been done in cooperation among stakeholders, and this has led to mutual benefits ${ }^{14}$. Also important in the development of schemes is cooperation with different scientific disciplines to extract baseline information about the farmers' willingness to engage in conservation actions, which is affected by many parameters ${ }^{10}$. To successfully implement the schemes, support is needed from a broad range of people from governments to businesses, and from farmers to local residents. Financial support is often crucial, but advice, feedback, and recommendations of measures that farmers feel positive about also increase the likelihood of the scheme to be effective ${ }^{6}$.

The starting point of this paper is literature on farmers' attitudes to nature conservation, and from the literature a farming context description was done. We have included farming business, farming policy, nature around the farm, extension, agri-environmental schemes, and other farmers as parts of the context. There is a need to know what the farmers see as main problems in the current policy, learn what makes them interested in nature, and determine what social and political parameters are effective incentives and disincentives in regulations and schemes for combining farming and conservation. How is the context affecting farmers' attitudes and behavior, and thus their influence on nature and nature conservation? Do subsidies or enrollment in agri-environmental schemes increase farmers' awareness of environmental issues?

The discussion in this paper focuses on how agrienvironmental schemes, as part of the incentive structure for change and action created by society, affect farmers' intent to implement actions in nature conservation issues and the reasons behind the farmers' decisions to join agrienvironmental schemes. Our goal is to provide an overview and critical examination of the current knowledge about farmers' perceptions of nature conservation and other factors influencing their willingness to perform nature conservation actions. Based on the literature, we developed a model (see Fig. 1) to show how relevant parameters influence the farmers and their effect on nature. Our state of departure is a farmer managing the farm according to a certain management regime that has a certain influence on biodiversity. We want to explore and show what factors are important and how these factors influence the management of the farm and especially so when another actor, for example, a governmental agency, takes action to change the management of the farm.

We provide these insights and the model for conservation biologists conducting research in farming regions, decision makers who develop future agri-environmental schemes, educators training tomorrow's extension officers and nature conservationists, and researchers dealing with nature conservation issues through a combination of scientific disciplines.

\section{Methods}

We confined our review on attitudes to literature published in scientific journals. There is a broader information base available in reports (for example Toogood et al. ${ }^{15}$ ) and working papers, but in order to make this selection of studies transparent and standardized, we chose to only use easily accessible and peer-reviewed resources. The literature was collected until spring 2005 through databases available at Webspirs and ISI Web of Knowledge. The key words used were attitudes, perception, feelings, farmers, nature and nature conservation. We also followed current literature in the field, searched the reference lists for relevant articles, and added a few more recent publications. Our review includes studies from Europe, North America and Australia/New Zealand. The review provides a timely snapshot of what is known about farmers and nature conservation actions in these regions. Fishbein and Ajzen ${ }^{16}$ published the first paper to link attitudes and behavior (theory of reasoned action, TRA) and since then many papers have been published about attitude theory; we are aware of this literature, but do not discuss that further in this paper. We acknowledge the discussion and critique in Burton $^{17}$ and literature therein about the over-emphasis on attitudes as the main factor in the choice of actions and behavior. 


\section{Description of Farmers and their Context}

In this section, we summarize the literature about how farmers are described and how farmers perceive their political, economic, and natural context. How the context is perceived is personal, and thus two farmers will experience the same situation differently.

Farmers are often characterized as having ties to the land that give them deep awareness of natural cycles, appreciation for natural beauty and a sense of stewardship, but at the same time farmers are characterized as primarily utilitarian, causing misuse of the land ${ }^{18}$. Thus, farmers may both care for and pollute the land simultaneously ${ }^{19,20}$. Farmers in the USA claim that they are good stewards and $82 \%$ describe themselves as sustainable managers of land resources ${ }^{21}$, whereas in another study $90 \%$ of the farmers surveyed felt close to the earth ${ }^{22}$. Cultivating fields and managing the same land over generations give farmers a unique local knowledge and thus a good understanding of how to care for and conserve land for future generations ${ }^{23}$.

McGregor et al. ${ }^{24}$ showed that UK farmers claim that coping with new legislation is as stressful as coping with the weather. 'Over-regulation' of farming is seen as a major threat for recruitment of new farmers in some areas in Germany ${ }^{23}$ and in the USA ${ }^{22}$. Personal benefits of farming include independence, and being close to nature because of the continuous opportunity to be outdoors ${ }^{18,25}$. In a study in Michigan, what farmers liked most with farming was independence but what they would miss the most if they left farming was their association with nature ${ }^{18}$. Farmers in US states of California and Colorado shared a love for the land and took pride in their work; camaraderie with other farmers was also important to them ${ }^{22,26}$. Farmers' discussions with other farmers, as well as with advisors and non-farm neighbors, are an important part of the rural community in the Netherlands ${ }^{27}$. To be acknowledged as a good farmer in the farming community in the UK, the appearance of the farm is important: straight planted crops, tidy ditches and managed hedges ${ }^{28}$.

There is a fear among farmers of losing control over the land, and as a result of this fear $56 \%$ of US farmers would not allow a biological survey of their land to avoid the risk of having their land regulated ${ }^{29}$. Likewise, there is concern about the potential for official designation of endangered species on their land that may limit decisions in management. 'Farmers (in the UK) knew that their farming practices worked with nature and logically that was why wildlife had flourished ${ }^{30}$ and these farmers also said if they had done anything wrong and destroyed habitat there would be nothing to preserve. They concluded that they must have been practicing conservation. Participation in conservation programs in the UK led in many cases to increased awareness of wildlife species ${ }^{31}$. In cases where biologists/ conservationists in the UK had taken time to show and name species made the farmer proud and more willing to take conservation actions because he or she knew what was being protected ${ }^{31}$.
In the UK, there was mistrust by farmers toward experts from the commercial input and processing sectors ${ }^{28}$. In contrast, Dutch conventional farmers preferred advice from suppliers or the bank over governmental representatives ${ }^{25}$. Clark and Murdoch ${ }^{32}$ showed that advice based only on science would not appear 'correct' to all farmers. The advice from experts was not seen as flexible enough, and farmers saw the lack of local and time-specific understandings of nature in the generalized recommendations.

Van der Meulen et al. ${ }^{27}$ showed that the Dutch farmer's first impression of the conservation scheme, and more importantly the first impression of the person presenting the scheme over the phone, affected whether the farmer would join or not. For example, high levels of adoption of woody conservation stream protection plantings were found in one county in Nebraska, where the extension educator enthused about these practices, compared to neighboring counties where there was less official interest ${ }^{33}$. To entice farmers to apply conservation practices, these actions must be put into the larger context of the goals of the farm, both in the short and long term. Goals have to be realistic, or no one will move them seriously into actions. People working with the administration of programs have to be competent in the subject as well as in communication with clients, and committed to the purpose and results of programs ${ }^{34}$.

Entering a conservation scheme and becoming aware of conservation is not the same thing ${ }^{30,35}$. The attitudes of farmers entering schemes decide the quality of the result ${ }^{35}$ A positive change in attitude will give greater conservation success and more conservation goods per unit of input money invested ${ }^{36}$.

\section{Farmer Concepts of Stewardship and Conservation}

'The love of the land' ${ }^{22,26}$ is one way to express stewardship. Here, we explore the term stewardship in the 'attitude' literature and see how it is used and described. If there is a defined stewardship feeling would it be possible to create agri-environmental schemes that support and enrich this stewardship and create successful schemes to be used by proud and still independent farmers?

'Landscape is not primarily to be conserved or preserved but to be cultivated and shaped' according to Finnish farmers ${ }^{37}$. The cultivation of the landscape, however, has to be done in harmony with nature without exploiting the land. Farming can be an act of stewardship. In a study from the $\mathrm{UK}^{30}$ a farmer stated that farming depends on "what the land would let you do'. It requires flexible management of the land depending on weather, local soils and fluctuating and unpredictable precipitation. Beedell and Rehman ${ }^{38}$ stated that UK farmers feel they have a moral obligation to take care of the countryside, and US respondents in Duram's ${ }^{26}$ study said that they farmed because it 'is a challenge' and 'for land stewardship'. Fairweather and Campbell $^{39}$ found that most New Zealand farmers 
responded positively to the statement, "rather than controlling nature, we need to learn to coexist with the natural environment'.

Farmers in the US Midwest were more interested in joining conservation programs that gave tidy managed habitats than programs creating untidy habitats without management such as natural growth in forests or riparian buffers $^{40}$. An aesthetically pleasing, i.e. tidy, landscape conveys the message, to other farmers, that the manager of this land is a good steward. However, biologists might differ in their reaction to these well defined and managed 'wildlife habitats', considering them more likely an area devoid of natural variation and niches ${ }^{40}$.

Professed sympathy towards nature conservation in the UK is argued to be overestimated ${ }^{41}$, as the attitudes and statements expressed in many surveys are not related to real actions or management. The gap between attitude and action was shown by Wicker ${ }^{42}$ in many social groups. There is also a great difference among stakeholders regarding the meaning of nature conservation. Carr and Tait ${ }^{41}$ describe how farmers see themselves as conservationists, but conservationists do not agree. Farmers in southwest England described with pride how they tried to maintain landscape features such as hedges, and how they never deliberately damaged nature ${ }^{31}$. However, it was uncommon to find active work with nature conservation on the farm, and few farmers had ever taken conservation advice.

Stewardship feeling does not always lead to management changes. Economic matters, for instance ${ }^{43}$, might stop the stewardship from being realized. An opinion, attitude, or perception does not have any effect until behaviors and actions change according to these factors. Vanclay ${ }^{44}$ and Millar and Curtis ${ }^{43}$ showed that farmers in Australia were concerned about conservation but they also reported that other factors, in this case economics, challenged the conservation concern.

In a study by McCann et al. ${ }^{45}$, organic and conventional farmers in Michigan varied in their adoption of conservation practices, but they shared a common concern for the environmental impact of agriculture. For organic farmers, this environmental concern was manifested in adoption of sustainable practices, but for the conventional farmers the same concern did not cause behavioral change. However, in the Netherlands the common concern among conventional and organic farmers was in economic matters, but they differed greatly in their view of nature ${ }^{25}$. For conventional farmers, nature meant economic values and they stated, 'we have to control nature'. To the organic farmers, nature meant a normative principle and farmers should 'go with the flow' of nature ${ }^{25}$. Similar results were found in Norway $^{46}$.

Pyrovetsi and Daoutopoulus ${ }^{47}$ found that farmers in a wetland area in Greece did not know or care about the environmental impacts of modern agriculture. Farmers were often concerned about general environmental issues on a community level but usually did not consider their farming practices as part of the problem ${ }^{37,44}$.
Stewardship and conservation are terms that mean different things to different people. Carr and Tait ${ }^{41}$ showed that farmers claim that they conserve the agricultural landscape and farming, while biological conservationists did not see that as conservation. Conservation for the latter was, instead, the species and habitats in each agricultural landscape. The same kind of reasoning can be done with stewardship. In the farmer's community to be a good steward of the land is in great contrast to the conservationists' definition of being a good steward. Ryan et al. ${ }^{40}$ showed that farmers wanted tidy habitats, whereas conservationists wanted untidy or diverse habitats. Thus dependent on the observer, the habitat is an example of good or bad stewardship if it is untidy. The clashes of opinions between farmers and conservationists are a key obstacle for sound nature conservation in the agricultural landscape.

\section{Factors Affecting Conservation Action Decisions}

\section{Economics}

As with any individual or company, economics of farming is important. But is this the only driver for farmers? Subsidies through agri-environmental schemes may be enough to create positive effects during the scheme period, but we need to examine if they serve as a stimulus to do new things and change perceptions about other questions, and thus continue to have positive effects beyond the period of the scheme and subsidies.

'If it was just a matter of economics we would not be here', said an English farmer as reported by Harrison et al. $^{30}$. Farmers' decisions are made under great external pressure from the market, national laws, regulations and subsidy programs. In a social climate where society demands cheaper food, and at the same time more environmentally friendly production practices, it is even harder for farmers to make management decisions. One incentive to farm in the UK was income, but at least as important was maintaining a nice place to live, being close to the land and nature, and independence ${ }^{23,27,48}$. The independence can be a threat as well, as many farmers in Greece felt trapped in farming, especially since they could not see how to make the farm more profitable ${ }^{47}$.

The economic pressures on the farm may work against the application of conservation actions ${ }^{45}$. Farmers perceive that it is possible to earn money producing high yields with one or two well-adapted crops, while it is harder to increase profitability by enhancing biodiversity through a broader mix of crop species, given current economics and price support structures. To make the farm business profitable or at least not an economic drain puts agricultural production before conservation ${ }^{49}$. According to Carr and Tait ${ }^{41}$, profit motives were stronger than environmental motives, even though farmers in the UK were aware of environmental problems. In the USA and UK the use of chemicals in 
farming was greater with higher farm income, but with increased farm income also came increased usage of alternative practices and enrollment in more conservation programs $^{50,51}$. Funding through federal programs in the USA was the trigger to start conservation efforts but it did not change the farmers' conservation attitudes. If the farmers' attitudes toward conservation had been negative, then funding had minimal and short-term impacts on their actions. However, funding was claimed to be good because it introduced farmers to new ways of doing things and to new people, to learning about what nature could do to solve a production dilemma, and learning how to live with social pressure after using less conventional management ${ }^{52}$. Ryan et al. ${ }^{40}$ showed that subsidies alone were neither enough to create a willingness to join conservation programs in the USA, nor did they create a long-term and useful conservation ethic. Another problem in farming in the developed world is the heavy dependence on agricultural subsidies. Finnish farmers were annoyed that 'desk-work' was greater rewarded than 'real work', their physical activity with visible results ${ }^{37}$.

The literature shows that farmers might be aware of environmental problems but they do not see their farming operation as a part of the problem, and thus there is no need to change anything. Other farmers might see the environmental problem and see their operation as part of the problem, but the economic situation on the farm does not permit conservation actions to be taken. Another prerequisite to join or to not join a scheme is the awareness that production and management methods might be both a cause of a decrease and an increase in farmland biodiversity ${ }^{14}$. Often farms with high income try to maximize profit and efficiency in all parts of the farm business, and that might lead to situations where the actions seem to contradict each other, e.g. pesticides ${ }^{50,51}$. The farmers need to feel supported not only with money but also with advice and engagement. Furthermore, it is important that farmers do not feel trapped in a rigid scheme, but still feel that their knowledge about production and nature is considered as an important input in the development and the realization of nature conservation in farmland.

Being a farmer is not simply a profession but a way of life and thus money is not all that matters; quality of life and independence are important. However, the fact that a larger and larger proportion of farm families earn their main income outside the farm might be the beginning of a disconnection of the tight bonds between the farmer and the land. An example is that working off farm and doing farming in spare time will lead to a great need to be fast, and a higher risk of doing the management actions when there is time, rather than doing specific operations when it is optimal to perform the actions.

\section{Farm demographics}

To better understand the impact of demographics on decisions, it is useful to examine such factors as farm size, farmer age, farm history and plans for the future. Farmers on small-scale farms in the USA express more concern toward environmental issues and incorporate more conservation strategies than farmers on industrial-scale farms ${ }^{53,54}$. The farmer population in the USA has changed during the past 50 years from a relatively homogeneous group of small- and medium-sized diverse family farms to today's specialized, large-scale units ${ }^{55}$.

Traore $^{56}$ found that neither farm size nor plans for heirs to continue farming were correlated with adoption of conservation techniques in Canada. In contrast, Featherstone and Goodwin ${ }^{57}$ found that larger farms and farmers in the USA with long-term plans for heirs to continue farming were more likely to invest in conservation measures than smaller farms. These conflicting results suggest that there are no simple answers to the question of how farm size and conservation are related.

Several studies claim that older farmers are less willing to use land-use planning and/or change farm management practices $^{58-60}$. Other studies show that younger and more educated farmers tend to be more willing to adopt new technologies and join conservation schemes ${ }^{61,62}$. Farmers living on an old family farm seemed to have developed greater sympathy with the land and also appeared more interested in conservation-oriented farming, compared to relative newcomers to farming ${ }^{63}$. Ownership of a farm creates emotional links and willingness to honor and maintain the status of the land ${ }^{64}$.

Farmers with successors seemed more willing to employ environmentally friendly farming practices ${ }^{63}$. However, organic farmers in the Netherlands seemed less concerned than conventional farmers about keeping the farm in the family and claimed that continued farming was more important for society than for the family ${ }^{25}$. The highest ranked reasons to join nature conservation in a study by Ryan et al. $^{40}$ were to conserve the land for future generations and feeling attached to one's land.

According to the reviewed studies there are scattered and contradictory ideas on how farm size, farm history, farmer age and education, and heirs on the farm affect the farmers' willingness to perform nature conservation actions. The younger and more educated farmers often tend to be more business-minded and thus more willing to try new methods and management practices in conservation and management issues. This might lead to conflicting actions: more pesticides but also more conservation actions. The future of many farms is unknown since many of them lack heirs, but how this will affect nature conservation issues cannot be determined from the literature we consulted.

\section{Discussion and Reflections}

We have found in the literature that farmers are often characterized as independent, close to nature and the environment, and concerned about natural resources. Yet 


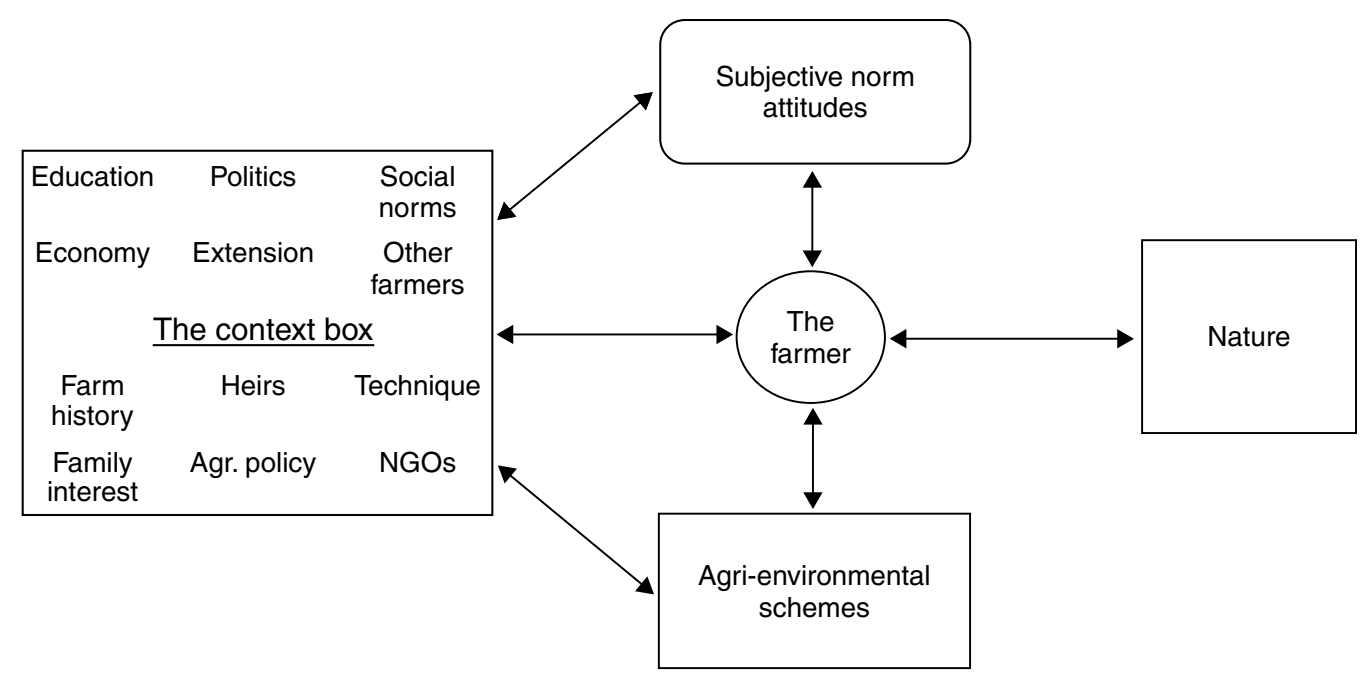

Figure 1. Attitudes and perceptions of farmers as affected by nature, context, and agri-environmental systems. The farmer is in the center of this model and thus the context box contains factors important for farmers. Deeper explanatory text to the model is included in the text.

this proximity to nature and natural systems does not necessarily seem to translate into a conservation ethic, nor does proximity to nature always result in farming practice and management decisions that are not primarily utilitarian. The interplay between the farmer and his or her context and attitudes and norms is more complex, which we illustrate by a model.

The model shown in Figure 1 consists of the farmer (age, sex, etc. included in this circle), his/her attitudes under everlasting and (fast) change depending on mood and situation (the reviewed literature captures these attitudes), nature and the farmer's effect on nature (attitudes change fast but the farming practices will not, thus there is a huge time lag between idea and change in behavior), the context box including several impacting factors, and finally the box with agri-environmental schemes. These schemes are a part of the context, but due to the focus of this article they are represented outside the context box to make it easier to see the connection to other parameters. We hope that our model can work as an eye-opener or a reminder to look outside the farm and inside the farmer when working with farming, agri-environmental schemes and nature conservation. We encourage policy-makers to consider the dynamics and complexity surrounding the farmer when making new, and applying present, agri-environmental schemes.

A farmer manages the farm to achieve certain goals, and to reach these goals certain means are used. The farmer has a certain perspective on the land and land-use, for example the farmer is aware of some changes and some issues in the current context (often technology, economy or policy) but is unaware of others (often nature conservation). The perspective of the farmer depends on how the farmer perceives the context in which he or she operates. Important context factors can be agri-environmental schemes, economics, extension, farm history, technology and social norms. Social norms are standards of behavior based on shared beliefs about how individuals should act ${ }^{65}$ and are constituted when members in a group, in these case farmers, have expectations of how other members in the group think, believe, know and act. In line with social norms is social identity ${ }^{66,67}$ — what social group the actor identifies with and thus what norms should be followed. In the review, we find a general, however vague, farmer identity but there are probably many farmer identities, defined either by the farmers themselves (e.g. milk producers, cereal growers, organic farmers, efficient farmers and traditional farmers) or defined by the surrounding society (e.g. old $>60$ years farmers, large $>200$ ha of arable land farmers and small scale $<5$ ha of arable land farmers).

The norms in the group are developed and maintained through interactions between the group members, and between groups and the rest of the context. The mindset of a farmer and feelings as a member, e.g. of the dairy farmers' group, is developed through comparison with other farmers in the group, other farmers outside the group and people outside the farming community.

When society tries to encourage the farmer to change management behavior, through politics via agri-environmental schemes, the farmer implicitly is offered a new identity and a new set of social norms. The changes in management can be challenged by the identity and the norms that the farmers already possess. There can be a great difference between social norms, actions approved by others; the subjective norm, the beliefs of what actions are approved by others; and attitudes and actions of the individual farmer ${ }^{16,17}$. In the study of Burgess et al. ${ }^{68}$, farmers saw themselves as food producers. The subjective norm (attitude) is being a food producer, and thus their subjective norm (attitude) is working against the social norm suggested by nature conservation agencies, NGOs and the common opinion in society that the farmer should also be a conservationist. The enrollment process in agrienvironmental schemes is thus a violation of the subjective 
norm. Thus many farmers may be reluctant to join a scheme, but that does not necessarily mean that they do not want to provide conservation services, i.e. they balk at the form not the content.

All farmers also have personal attitudes. There are several definitions of attitudes, ranging from theoreticalattitudes are readiness to act ${ }^{69}$, to operational-attitudes as they are measured in attitude tests. The fruitfulness of the very concept of attitudes has been debated by scholars ${ }^{4}$. Attitudes are neither permanent nor static and they are recreated each time we respond to a question, a behavior or a specific occurrence ${ }^{70}$. Thus, to conclude that a farmer has a certain attitude when it comes to management of the farm and nature is a pure speculation. In our theoretical model (Fig. 1), we use a theoretical definition of attitudes. We define attitudes as a readiness to act or a mindset that is used by an actor to act and judge in situations of decisionmaking. The literature that we have reviewed represents the attitudes the respondents each express in that specific interview or questionnaire situation. We want to stress that to express an opinion by heart, 'I see myself as a sustainable farmer' in an interview or to agree with a statement, 'Are your farming operations sustainable?' in a questionnaire demands different interpretations. To highlight this, attitudes are represented in our model (Fig. 1) by a box outside the farmer but in constant development by the farmer in interaction with his or her context. The attitudes are also outside the farmer to show that there can be a fast turnover of attitudes.

It is easy to express a wish to change the management of the farm to be more environmentally friendly but much harder and more time consuming to actually change behavior that ultimately has an impact on nature. The attitudes of the farmer are dependent on the norms that exist in the group/s that the farmer identifies with. From the reviewed literature, it seems to be a part of the farmers' norm to claim to be a steward of the land who cares for nature. However, if simultaneously asked how he or she wants to see and manage uncultivated areas, field islands, or riparian strips, the farmers' norms suggest an answer of tidy and clean habitats, which is behavior not promoting nature conservation and biodiversity. Attitudes cannot be studied as only personal parameters as they depend on the context, and especially social factors. This does not mean that every member in the group has an attitude corresponding to the group's attitude. Group members may have extreme opinions in comparison to others in the group, but still they depend on the group norms.

Farmers also act in correspondence with their experience of the physical prerequisites shown in the context box in Fig. 1: economics, social factors, knowledge and technology. If the farmer is unable to comply with the agrienvironmental scheme due to these prerequisites, then extension and subsidies will have no effect. The important factor is how the farmer perceives his or her possibilities to act in accordance with the policies, laws and regulations. The farmer has to account for how he or she perceives the farm being affected by the change caused by the entry in agri-environmental schemes, for example:

- How the farm economy is affected by the change; what are the financial risks of joining; and how big a risk is he or she is willing to take?

- How the change will affect relations in the family, with other farmers and with neighbors.

- Does the farmer have enough knowledge to perform the management changes and whether or not he or she can judge the consequences of the changes for the farm?

- Can the farmer can get access to the technology needed for the change in management?

We identify three main ways to influence agriculture's effect on biodiversity: rules and regulations, financial incentives [e.g. subsidies such as agri-environmental schemes (AES), which also are conditioned to regulations] or better payment (branded production), and change in the mindset of farmers. The incentives can be explained in other words by people in nature conservation agencies. An example is pesticide use. 'You are not allowed to spray'; 'If you spray less, we compensate you for the yield loss' or 'We pay you more for your product if you spray less'. Or, 'We have problems with pesticide residues in the groundwater and this can affect the water quality in your own well'. If explained from the farmer perspective, it may be quite different. 'I am not allowed to spray and I am obliged to and want to follow the law'. 'Since my yield loss is compensated I spray less' or 'Since I get higher price for my product I spray less', 'I see my use of pesticides as part of the problem with pesticide residues in the groundwater and later in my drinking water, and so I will try to find alternative methods and/or spray only when it is really needed'.

Subsidies can be a starting point to change farmers' thinking, especially if combined with education and extension. Kleijn and Sutherland ${ }^{6}$ state that programs where the payment is reasonable and a scheme promotes the farmers' knowledge and increases positive feelings for the habitat or action, then the likelihood of a long-term success is higher. Aldo Leopold has expressed the same idea in the following words: 'Once you learn to read the land, I have no fear of what you will do to it, or with it. And I know many pleasant things it will do to you' ${ }^{71}$.

\section{Development of New AES}

Good stewards adapt to changes and develop their management units according to their experiences and attitudes towards the land. Nordström Källström and Ljung $^{72}$ state that many farmers perceive the lack of control of the decision-making process for the farm as the most important factor that hinders their ability to continue farming. Farmers often do not feel empowered to initiate modifications of farm management, and feel stifled by rigid requirements that turn out to be detrimental to adoption of schemes if there is little flexibility. We agree that '... by 
adopting a more inclusionary and participatory approach, conservation (in the UK and elsewhere) can benefit both wildlife and people in ways that currently appear to be precluded by the dominance of a scientific approach (noninclusive and participatory) ${ }^{, 73}$. The agri-environmental schemes ought to be so flexible that farm-specific solutions can be allowed if they can help fulfill the goals and follow the principles of the scheme. As Davis ${ }^{34}$ said, 'Don't fall in love with your computer, or with your guides, or with your standards [agri-environmental schemes] ....

It is not the fulfillment of each and every detail of the scheme that is important but the fulfillment of the overall aims of the schemes. Unfortunately, today it seems as if the dominating opinion is that rigid schemes are easier to evaluate and control, and therefore they are widely used. However, by trying to fit schemes to administration rather than to nature and people we lose the ability of local adaptations and thus the possibility to create truly effective agri-environmental schemes. Leopold puts it in another way in his book about land ethics: 'In our attempt to make conservation easy, we have made it trivial ${ }^{71}$.

\section{Concluding Remarks}

The results from the literature sometimes contain both contradictions and paradoxes. The literature shows a great diversity of attitudes and, since attitudes are not static, change even within an individual and among individuals will differ, thus generalizations are hard to make. We agree with Burton ${ }^{17}$ that there appears to be an over-confidence in attitudes as a main driver of action, and there is also an unsound belief in the power of attitude studies to reveal the true intentions of stakeholders. However, since farmers impact conservation practices and decisions, incorporating some of the knowledge from attitude studies in the design of new agri-environmental schemes is likely to be better than giving no consideration to the 'soft values' expressed by farmers.

Further research must be able to handle paradoxes and embrace rather than shrink back from them. The combinations of scientific disciplines are one way to deal with paradoxes. Research design must include ample time, since for example several meetings with the same farmer will increase the probability of uncovering paradoxes in farm management and nature conservation. Economics of the farm will often be mentioned in the interviews but if the interview technique allows several meetings then other reasons and explanations will appear ${ }^{4}$. We hope that coming research and publications will spread more light over the complex reality of farming and conservation in the agricultural landscape, and help us understand better how farmers' attitudes shape compliance with environmentally driven subsidy goals.

Acknowledgements. We thank J. Bengtsson, J. Björklund, two anonymous referees and the editors for valuable comments on the manuscript. FORMAS, Ekhaga Foundation and Oscar and
Lili Lamm's foundation have given financial support to the first author.

\section{References}

1 Benton, T.G., Bryant, D.M., Cole, L., and Crick, H.Q.P. 2002. Linking agricultural practices to insect and bird populations: a historical study over three decades. Journal of Applied Ecology 39:673-687.

2 Fuller, R.J., Gregory, R.D., Gibbons, D.W., Marchant, J.H., Wilson, J.D., Baillie, S.R., and Carter, N. 1995. Population declines and range contractions among lowland farmland birds in Britain. Conservation Biology 9:1425-1441.

3 Krebs, J.R., Wilson, J.D., Bradbury, R.B., and Siriwardena, G.M. 1999. The second silent spring. Nature 400:611-612.

4 Siebert, R., Toogood, M., and Knierim, A. 2006. Factors affecting European farmers' participation in biodiversity policies. Sociologia Ruralis 46:318-340.

5 Kleijn, D., Berense, F., and Gilissen, N. 2001. Agrienvironmental schemes do not effectively protect biodiversity in Dutch agricultural landscapes. Nature 43:723-725.

6 Kleijn, D. and Sutherland, W.J. 2003. How effective are European agri-environmental schemes in conserving and promoting biodiversity? Journal of Applied Ecology 40:947-969.

7 Knop, K., Kleijn, D., Herzog, F., and Schmid, B. 2006. Effectiveness of the Swiss agri-environmental scheme in promoting biodiversity. Journal of Applied Ecology 43:120 127.

8 Carey, P.D., Manchester, S.J., and Firbank, L.G. 2005. Performance of two agri-environmental schemes in England: a comparison of ecological and multi-disciplinary evaluations. Agriculture, Ecosystems and Environment 108:178-188.

9 Bengtsson, J., Ahnström, J., and Weibull, A.-C. 2005. The effects of organic agriculture on biodiversity and abundance: a meta-analysis. Journal of Applied Ecology 42:261-269.

10 Mattison, H.A. and Norris, K. 2005. Bridging the gaps between agricultural policy, land-use and biodiversity. Trends in Ecology and Evolution 20:610-616.

11 Benton, T.G., Vickery, J.A., and Wilson, J.D. 2003. Farmland biodiversity: is habitat heterogeneity the key? Trends in Ecology and Evolution 18:182-188.

12 Firbank, L.G. 2005. Striking new balance between agricultural production and biodiversity. Annals of Applied Biology 146:163-175.

13 Feehan, J., Gillmor, D.A., and Culleton, N. 2005. Effects of an agri-environmental scheme on farmland biodiversity in Ireland. Agriculture, Ecosystems and Environment 107:275286.

14 Smallshire, D., Robertson, P., and Thompson, P. 2004. Policy into practice: the development and delivery of agrienvironmental schemes and supporting advice. IBIS 146:250258.

15 Toogood, M., Gilbert, K., and Rientjes, S. 2004. Farmers and the environment. Assessing the factors that affect farmers' willingness and ability to cooperate with biodiversity policies. Biofact, European Centre for Nature Conservation, Wageningen, the Netherlands.

16 Fishbein, M. and Ajzen, I. 1975. Belief, Attitude, Intention, and Behaviour: An Introduction to Theory and Research. Addison-Wesley, Reading, MA, USA. 
17 Burton, R.J.F. 2004. Reconceptualising the 'behavioural approach' in the agricultural studies: a socio-psychological perspective. Journal of Rural Studies 20:359-371.

18 Sullivan, S., McCann, E., De Young, R., and Erickson, D.L. 1996. Farmers' attitudes about farming and the environment: a survey of conventional and organic farmers. Journal of Agricultural and Environmental Ethics 9:123-143.

19 Trembley, K.R. and Dunlap, R.E. 1978. Rural-urban residence and concern with environmental quality: a replication and extension. Rural Sociology 43:474-491.

20 Westmacott, R. 1983. The conservation of farmed landscapes: attitudes and problems in the United States and Britain. Landscape Design 144:11-14.

21 Hanson, J.C., Kauffman, C.S., and Schauer, A. 1995. Attitudes and practices of sustainable farmers, with applications to designing a sustainable agricultural program. Journal of Sustainable Agriculture 6:135-156.

22 Liffman, R.H., Huntsinger, L., and Forero, L.C. 2000. To ranch or not to ranch: home on the urban range? Journal of Range Management 53:362-370.

23 Bieling, C. and Plieninger, T. 2003. 'Stinking, diseasespreading brutes' or 'four-legged landscape managers'? Livestock, pastoralism, and society in Germany and the USA. Outlook on Agriculture 32:7-12.

24 McGregor, M.M., Willock, J., and Deary, I.J. 1995. Farmer stress. Farm Management 9:57-65.

25 Schoon, B. and Te Grotenhuis, R. 2000. Values of farmers, sustainability and agricultural policy. Journal of Agricultural and Environmental Ethics 12:17-27.

26 Duram, L.A. 1999. Factors in organic farmers' decision making: diversity, challenge, and obstacles. American Journal of Alternative Agriculture 14:2-9.

27 van der Meulen, H.A.B., de Snoo, G.R., and Wossink, G.A.A. 1996. Farmers' perception of unsprayed crop edges in the Netherlands. Journal of Environmental Management 47:241-255.

28 Oreszczyn, S. and Lane, A. 2000. The meaning of hedgerows in the English landscape: different stakeholder perspectives and the implications for future hedge management. Journal of Environmental Management 60:101-118.

29 Brook, A., Zind, M., and DeYoung, R. 2003. Landowners' responses to an endangered species act listing and implications for encouraging conservation. Conservation Biology 17: $1638-1649$.

30 Harrison, C.M., Burgess, J., and Clark, J. 1998. Discounted knowledges: farmers' and residents' understandings of nature conservation goals and policies. Journal of Environmental Management 54:305-320.

31 Battershill, M.R.J. and Gilg, A.W. 1996. New approaches to creative conservation on farms in South-west England. Journal of Environmental Management 48:321-340.

32 Clark, J. and Murdoch, J. 1997. Local knowledge and the precarious extension of scientific networks: a reflection on three case studies. Sociologia Ruralis 37:38-60.

33 Skelton, P., Josiah, S.J., King, J., Brandle, J.R., Helmers, G., and Francis, C.A. 2005. Adoption of riparian forest buffers on private lands. Journal of Small-Scale Forest Economics, Management, and Policy 4:185-204.

34 Davis, R.M. 1985. Conservation: a matter of motivation. Journal of Soil and Water Conservation 40:400-402.

35 Morris, C. and Potter, C. 1995. Recruiting the new conservationists: farmers' adoption of agri-environmental schemes in the UK. Journal of Rural Studies 11:51-63.
36 Coleman, D., Crabtree, B., Fround, J., and O'Carrol, L. 1992. Comparative Effectiveness of Conservation Mechanisms. Manchester University, UK.

37 Silvasti, T. 2003. The cultural model of 'the good farmer' and the environmental question in Finland. Agriculture and Human Values 20:143-150.

38 Beedell, J.D.C. and Rehman, T. 1999. Explaining farmers' conservation behavior: why do farmers behave the way they do? Journal of Environmental Management 57:165-176.

39 Fairweather, J.R. and Campbell, H.R. 2003. Environmental beliefs and farm practices of New Zealand farmers: contrasting pathways to sustainability. Agriculture and Human Values 20:287-300.

40 Ryan, R.L., Erickson, D.L., and De Young, R. 2003. Farmers' motivations for adopting conservation practices along riparian zones in a Mid-western agricultural watershed. Journal of Environmental Planning and Management 46:19-37.

41 Carr, S. and Tait, J. 1991. Differences in the attitudes of farmers and conservationists and their implications. Journal of Environmental Management 32:281-294.

42 Wicker, A.W. 1969. Attitudes versus actions: the relationship of verbal and overt behavioral responses to attitude objects. Journal of Rural Studies 11:51-63.

43 Millar, J. and Curtis, A. 1999. Challenging the boundaries of local and scientific knowledge in Australia: opportunities for social learning in managing temperate upland pastures. Agriculture and Human Values 16:389-399.

44 Vanclay, F. 1992. The social context of farmers' adoption of environmentally sound farming practices. In G. Lawrence, F. Vanclay, and B. Furze (eds). Agriculture, Environment and Society. Macmillan, Melbourne, Victoria, Australia.

45 McCann, E., Shannon, S., Erickson, D., and Young, R.D. 1997. Environmental awareness, economic orientation, and farming practices: a comparison of organic and conventional farmers. Environmental Management 21:747-758.

46 Storstad, O. and Bjørkhaug, H. 2003. Foundations of production and consumption of organic food in Norway: common attitudes among farmers and consumers? Agriculture and Human Values 20:151-163.

47 Pyrovetsi, M. and Daoutopoulus, G. 1999. Farmers' need for nature conservation education in Greece. Journal of Environmental Management 56:147-157.

48 Willock, J., Deary, I.J., McGregor, M., Sutherland, A., EdwardsJones, G., Morgan, O., Dent, B., Grieve, R., Gibson, G., and Austin, E. 1999. Farmers' attitudes, objectives, behaviors, and personality traits: the Edinburgh study of decision making on farms. Journal of Vocational Behavior 54:5-36.

49 Gasson, R. and Potter, C. 1988. Conservation through land diversion: a survey of farmers' attitudes. Journal of Agricultural Economics 39:340-351.

50 Dick, R. 1992. Sustainability, can it be measured in agricultural systems? Fourth North American Symposium on Society and Resource Management, Madison, WI, USA.

51 Westmacott, R. and Worthington, T. 1984. Agricultural Landscapes: A Second look. Countryside Commission, Cheltenham, UK.

52 Trout, S.K., Francis, C.A., and Barbuto, J. Jr 2005. Impacts of the North-Central Region SARE grants, 1988-2002. Journal of Sustainable Agriculture 27:117-137.

53 Buttel, F.H. and Gillespie, G.W. Jr 1988. Preferences for crop production practices among conventional and 
alternative farmers. American Journal of Alternative Agriculture 3:11-17.

54 Filson, C.G. 1993. Cooperation differences in Ontario farmers' environmental attitudes. Journal of Agricultural and Environmental Ethics 6:165-184.

55 Albrecht, D.E. and Murdock, S.H. 1990. The Sociology of U.S. Agriculture: An Ecological Perspective. Iowa State University Press, Ames, IA, USA.

56 Traore, N. 1998. On-farm adoption of conservation practices: the role of farm and farmer characteristics, perceptions, and health hazards. Land Economics 74:114-128.

57 Featherstone, M.A. and Goodwin, B.K. 1993. Factors influencing a farmer's decision to invest in long-term conservation improvements. Land Economics 69:67-81.

58 Bultena, G.L., Nowak, P., Hoiberg, E., and Albrecht, D. 1981. Farmers' attitudes toward land use planning. Journal of Soil and Water Conservation 36:37-41.

59 Bultena, G.L. and Hoiberg, E.O. 1983. Factors affecting farmers' adoption of conservation tillage. Journal of Soil and Water Conservation 38:281-284.

60 Jacobsen, R.M., Youngs, G.A. Jr, Goreham, G.A., Watt, D.L., Dahl, B.L., Sell, R.S., and Stearns, L.D. 1991. Selected characteristics of North Dakota farm families engaged in sustainable agricultural practices. Agricultural Economics Report No. 271. Department of Agricultural Economics, North Dakota State University, Fargo, ND, USA.

61 Carlson, J.E. and McLeod, M.E. 1977. Farmers' attitudes toward soil erosion and related farm problems in the Lewis and Idaho county wheat region. Progress Report No. 198. University of Idaho, Moscow, ID, USA.
62 Gould, W., Saupe, W.E., and Klemme, R.M. 1989. Conservation tillage: the role of farm and operator characteristics and perception of soil erosion. Land Economics 65:167-181.

63 Wilson, G.A. 1996. Farmer environmental attitudes and ESA participation. Geoforum 27:115-131.

64 Segalen, M. 1987. Objets domestiques de la vie ouvrière. Transmissions et ruptures dans les familles de Nanterre (1920-1960). Ethnologie Française 17:29-38.

65 Fehr, E. and Fischbacher, U. 2004. Social norms and human cooperation. Trends in Cognitive Sciences 8:185-190.

66 Tajfel, H., Billig, M.G., Bundy, R.F., and Flament, C. 1971. Social categorization and intergroup behaviour. European Journal of Psychology 1:149-177.

67 Tajfel, H. (ed.). 1982. Social Identity and Intergroup Relations. Cambridge University Press, Cambridge, UK.

68 Burgess, J., Clark, J., and Harrison, C.M. 2000. Knowledge in action: an actor network analysis of a wetland agri-environmental scheme. Ecological Economics 35:119-132.

69 Jung, C.G. [1921] 1971. Psychological Types, Collected Works, Volume 6. Princeton University Press, Princeton, NJ, USA.

70 Eagly, A.H. and Chaiken, S. 1993. The Psychology of Attitudes. Harcourt Brace, Orlando, FL, USA.

71 Leopold, A. 1949. A Sand County Almanac and Sketches Here and There. Oxford University Press, NY, USA.

72 Nordström Källström, H. and Ljung, M. 2005. Social sustainability and collaborative learning. Ambio 34:376-382.

73 Harrison, C. and Burgess, J. 2000. Valuing nature in context: the contribution of common-good approaches. Biodiversity and Conservation 9:1115-1130. 